\title{
EFL Learners' Listening Strategy Awareness viewed from Their Learning Styles in the Extensive Listening Class
}

\author{
Dodi Mulyadi \\ Universitas Muhammadiyah Semarang, Semarang \\ dodi@unimus.ac.id
}

Article History: Submitted 25 November 2018; Accepted 28 November 2018; Published 31 December 2018

\begin{abstract}
Albeit listening comprehension as the vital role of language input, most EFL students have a somewhat negligent concern of it in the process of mastering EFL. Accordingly, the listening educators need to confirm students' listening strategy awareness related to their learning styles for enhancing the quality of teaching listening. To this end, the study aims at assaying EFL students' listening strategy awareness between visual, auditory, and kinesthetic learners who got an explicit strategy instruction of Extensive listening class and those who did not get the explicit strategy instruction. The participants of the study were 38 sophomore EFL students of English departments at Universitas Muhammadiyah Semarang. Listening strategy awareness questionnaire, learning style questionnaire, and interview were utilized as the data collection instruments. The results elucidated thatexplicit listening strategy instructions have raised students' direct attention strategies. Strategies of interpreting the meaning in their head and translating keywords that they have listened potentially impact on students' mental translation strategy awareness. Indeed, visual learners in the control group have a higher strategy awareness dealing with person knowledge than in an experimental group. Then, auditory learners have similar scores for both groups - meanwhile, a bit higher score of person knowledge possessed by the kinesthetic learners in the experimental group. However, the statistical findings elucidate that there are no significant differences between the experimental and control group. Interview results confim that explicit strategy instruction of extensive listening class enables learners to create a good atmosphere in listening class, and their competence of listening instruction.
\end{abstract}

Keywords: Explicit Strategy Instruction; Extensive Listening Class, Strategy Awareness, Learning Styles

Abstrak. Walaupun listening comprehension memiliki peranan yang sangat penting dalam pemerolehan bahasa, masih banyak siswa EFL yang mengabaikan pembelajaran listening tersebut dalam proses pembelajaran Bahasa Inggris sebagai bahasa asing. Oleh Karen itu, penelitian ini bertujuan untuk menganalisis penggunaan strategi yang dalam pembelajaran listening bagi mahasiswa visual, auditori, dan kinestetik yang telah mendapatkan perkulihan extensive listening dengan pengajaran strategi yang eksplisit. Partisipan dalam penelitian ini berjumlah 38 mahasiswa Bahasa Inggris di Universitas Muhammadiyah Semarang. Instrumen pengumpulan data meliputi Listening strategy use questionnaire, learning style questionnaire, dan interview. Hasil menunjukan bahwa pengajaran strategi listening secara eksplisit telah meningkatkan direct attention siswa. Strategi menafsirkan makna di kepala mereka dan menerjemahkan kata kunci yang mereka telah 
mendengarkan berdampak pada mental translation strategy awareness mereka. Akan tetapi visual learners dalam kelompok control memiliki strategy awareness terkait Person Knowledge lebih tinggi daripada dalam kelompok eksperimental. Auditory learners memiliki nilai yang sama untuk kedua kelompok. Sementara itu, sedikit lebih tinggi Skor orang pengetahuan yang dimiliki oleh para peserta didik kinestetik dalam kelompok eksperimental. Wawancara menunjukkan hasil bahwa strategi yang eksplisit instruksi kelas mendengarkan luas memungkinkan para peserta didik untuk menciptakan suasana yang baik dalam mendengarkan kelas, dan kompetensi mereka dalam mengajarkan materi listening.

Kata kunci: pengajaran strategi secara eksplisit; kelas extensive listening: kesadaran penggunaan strategi; gaya belajar

\section{INTRODUCTION}

Listening comprehension that plays a pivotal role in contributing the oral communication skill needs the provision of adequate practices. However, many EFL students have a somewhat negligent concern in the process of mastering foreign language (Vandergrift \& Goh, 2012). They encountered challenging listening tasks. They have been perplexed to grasp the meaning what they were listening to astream of sounds that necessitate their sufficient understanding of linguistic and world knowledge ( Vandergrift \& Baker, 2015;Kök, 2017). Accordingly, the listening educators should be able to adjust the apposite strategies for teaching listening class in order tofacilitate theirstudents to get in charge of the learning process.

The listening lecturers or teachers should be able to adjust students' listening strategy awareness to deal with various situations, types of input, and listening purposes. Recently, a considerable literature has grown up around that assaying metacognitive listening strategy awareness enable listening educators to enhance the quality of teaching listening class (Amin, 2011; Bidabadi \& Yamat, 2013; Graham, Santos, \& Vanderplank, 2008; Mehrak Rahimi \& Katal, 2012a; Siegel, 2013; Tafarojiyeganeh, 2013). To wit, they should have challenging tasks to enable students to develop a set of listening strategies and match the appropriate strategies for each listening situation and their listening purposes. Facilitating with knowing this language learning strategy, learners are getting in charge in thinking about the process of learning while they are planning, monitoring, and evaluating their own learning, for instance, pre-tasks activities. Holden in Serri et al. (2012) states that metacognitive strategies refer to the actions that learners use consciously while listening to a spoken text attentively. EFL learners that use metacognitive strategies and make decisions about whether to apply various strategies can develop and improve their listening performance employing in procedural knowledge such as learners' plan, solve problems and evaluate their tasks and performance.

However, knowing the students' listening strategy awareness is not sufficient for a listening educator to know the students' apposite listening strategy awareness. Accordingly, they need also to give an account to the learning styles as one factor of learners differences in mastering language (Mulyadi, Rukmini, \& Yuliasri, 2017). Knowing the learning styles of students can help a teacher to select the method and media for their teaching. The teacher can choose the appropriate teaching approach based on 
student learning preferences (Xu, 2011; Gilakjani, 2011). Hamdani's (2015) study asserts that ascertaining learner's learning styles enable the learning process to meet the appropriate teaching techniques for their individual learner. Therefore, the listening lecturers necessitate to consider the students' strategy awareness based on their learning stylesafter having an explicit strategy instruction. They need to be taught the explanation of every listening strategy for particular topic and activities during the learning process. To wit, the instructor of the listening subject needs to ensure that the learners are able to apply and evaluate that strategy.

\section{The Explicit Strategy Instruction in the Extensive Listening Class}

Research in metacognitive and cognitive learning strategy suggests that transfer of strategy training to new tasks can be maximized by pairing metacognitive strategies with appropriate cognitive strategies(O'Malley \& Chamot, 1995). Field (2008) states that "the distinction between cognitive and metacognitive is quite difficult to explain. Strategies that are 'metacognitive' in one context may turn out to be 'cognitive' in another." It means that the implementation of listening strategies between cognitive and metacognitive isvery hard to be separated in the learning process. For example, when the lecturer plans to listen out for stressed words in an utterance as the strategy qualifies as metacognitive, students do it as cognitive strategies. Therefore, cognitive and metacognitive strategies are integrated to be the treatment this present study. To wit, the explicit strategy instruction was conducted by following the steps of "(Meta)-cognitive listening strategy (M-CLS) instruction" by integrating the listening instruction of metacognitive listening strategies and cognitive listening strategies (Mulyadi, 2018).Incorporating strategy instruction into regular classes provided learners with opportunities to practice strategies in an authentic language-learning atmosphere and apply them in completing the tasks (Guan, 2014). The listening lecturer explains the value and purpose of a particular strategy to the students and then provides explicitinstruction on how to apply the strategies. They are conveyed to make students aware about what kind of strategiesused in teaching and learning process. Thus, the instructor of the listening subject needs to ensure that the learners are able to apply and evaluate the strategies for mastering a listening skill.

M-CLS instruction is implemented based on steps displayed in, for instance, the implementation of the M-CLS instruction for the first stage of M-CLS instruction is taught by explaining the goal of listening and activating their background knowledge(Mulyadi et al., 2017). They have to know the goals which they plan to reach success in mastering listening skill and how they set students to realize those goals (Fitrianingsih \& Udin, 2017).

Describing the goal of listening class is related to advance organizing of metacognitive strategies to give students' understanding of the objective of listening activities that will be discussed (Vandergrift in Birjandi, 2012). Activating background knowledge isintended to improve students' ability to interpret the message of listening text (Larry Vandergrift \& Goh, 2012).

The implementation of these strategies includes planning for listening class by telling the students about seeking the keywords information of the oral text. The students are taught about the strategy of activating their previous experience dealing with topics such as losing weight, stress, etc. Furthermore, cognitive process of predicting is also implemented by asking some questions related to the topics. Nation \& Newton (2009) states that this 
strategy can be conducted by asking learners to guess some information about what is going to happen in the listening text.

The second stage is related to monitoring comprehension. It is carried out by verifying their prediction in the planning stage. It is also undergone by checking their anticipated opinion to make them focus more on the listening gist (Abdelhafid, 2007). The next strategies are related to listening to keywords and main ideas that can be taken into notes. This note-takingis conducted by writing keywords and main idea concisely to assist performance of a listening task (Guan, 2014).Moreover, students can apply note-taking by jotting down the main points based on listening to compensate their memory constraints (Larry Vandergrift \& Goh, 2009)

To sharpen their listening comprehension dealing with listening tasks, listening text is played for the second time. Then, the learners are invited to have the third listen to do the next task. Guan (2014) states that inferencing can be used to get information from the listening text to guess the meanings of unfamiliar words or phrasesin accordance with doing the listening task, predicting outcomes, or completing missing information.

The third stage is dealt with post-listening activities. The lecturer holds the evaluation of students' listening comprehension in a particular task. The students are also requested to determine the appropriate strategies for understanding the oral text. Finally, they summarize the message or content what they have listened. It is utilized to disclose what the essential ones that they believe (Vandergrift cited in Abdelhafid, 2007).

To date, the considerable research on strategy awareness do not deem the learning styles and investigation on the explicit strategy instruction in the extensive listening class(AlAlwan, Asassfeh, \& Al-Shboul, 2013; Bidabadi \& Yamat, 2013; Chamot, 2004; Guan, 2014; Harris, 2008; Marzban \& Isazadeh, 2012; Mehrak Rahimi \& Abedi, 2014; Mehrak Rahimi \& Katal, 2012b). Accordingly, the present study investigated the learners' listening strategy awareness viewed from their learning styles in extensive listening class of students who got the explicit instructions and those who did not.

\section{METHOD}

\section{Research Design}

Quantitative and qualitative research designswereconducted in the present study to assay the EFL students' listening strategy awareness between visual, auditory, and kinesthetic learners who got an explicit instruction of listening class compared to the control group who did not get the explicit instruction of Teaching class.

\section{Participants}

The participants of the study were 38sophomore EFL students of English departments at Universitas Muhammadiyah Semarang. They were divided into two classes (19 in experimental class and 20 in control class). They have got the course of extensive listening class in year 2017-2018. The course was intended to facilitate them to be familiar with authentic listening texts and regular listening practice (Alm, 2013), especially by accommodating materials of the extensive listening class. The extensive listening course refers to learners doing a lot of easy, comprehensible, and enjoyable listening practice such 
as listening to audio books or radio programs (Chang \& Millett, 2014). It was included in the curriculum to facilitate students in mastering listening skills related to the real-life situation in order to be ready for communicating in English.

\section{Materials}

This subject was aimed at analyzing the content of the listening materials and understanding the chronology and the speaker's response related to a long conversation of the interview, Evaluating the specific information of long talk, making inference and review for the gist of news and speech, retelling story of short movies. The materials for ten meetings of an extensive listening instruction are enumerated in Table 1.

Table 1 The Materials of Extensive Listening Instruction

\begin{tabular}{|c|c|c|c|}
\hline Meetings & $\begin{array}{l}\text { Learning } \\
\text { Activities }\end{array}$ & Materials & Sources \\
\hline 1 & $\begin{array}{l}\text { Listeningto a } \\
\text { Long talk }\end{array}$ & $\begin{array}{l}\text { More Tolerance we need } \\
\text { more tourism conveyed } \\
\text { by Aziz Abu Sarah }\end{array}$ & TED.com \\
\hline 2 & $\begin{array}{l}\text { Listening to a } \\
\text { long talk }\end{array}$ & $\begin{array}{l}\text { I WannaTalk about } \\
\text { Learning Languages }\end{array}$ & $\begin{array}{l}\text { https://learnenglish.britishcou } \\
\text { ncil.org/en/i-wanna-talk- } \\
\text { about/learning-languages }\end{array}$ \\
\hline 3 & $\begin{array}{l}\text { Listening to the } \\
\text { Interview }\end{array}$ & losing weight & $\begin{array}{l}\text { (Greet, Judith. } \\
\text { 2005.Timesaver Intermediate } \\
\text { Listening. Scholastic } \\
\text { Glasgow: Mary Glasgow } \\
\text { Magazines }\end{array}$ \\
\hline 4 & $\begin{array}{l}\text { Listening to the } \\
\text { Interview }\end{array}$ & Stress & $\begin{array}{l}\text { Greet, Judith. } \\
\text { 2005.Timesaver Intermediate } \\
\text { Listening. Scholastic } \\
\text { Glasgow: Mary Glasgow } \\
\text { Magazines }\end{array}$ \\
\hline 5 & $\begin{array}{l}\text { Listening to } \\
\text { News }\end{array}$ & $\begin{array}{l}\text { Pools Turn Green at Rio } \\
\text { Olympics) by }\end{array}$ & $\begin{array}{l}\text { www.englishclub.com/efl/list } \\
\text { ening. }\end{array}$ \\
\hline 6 & $\begin{array}{l}\text { Listening to } \\
\text { speech }\end{array}$ & $\begin{array}{l}\text { Donald Trump, the } \\
\text { Speech That Will Make } \\
\text { Donald Trump } \\
\text { President. } \\
\text { Zamzam water (by }\end{array}$ & $\begin{array}{l}\text { Published on Sep 18, } 2016 . \\
\text { YouTube. }\end{array}$ \\
\hline 7 & $\begin{array}{l}\text { Listening to } \\
\text { video talk }\end{array}$ & EbanTakie) & $\begin{array}{l}\text { Published on May 23, } \\
\text { 2018https://www.youtube.co } \\
\text { m/watch?v=XgRt1pQy0Sg }\end{array}$ \\
\hline 8 & $\begin{array}{l}\text { Listening } \\
\text { comprehension } \\
\text { based on a short } \\
\text { movie }\end{array}$ & $\begin{array}{l}\text { Penelope in the } \\
\text { Treehouse) } \\
\text { Kierandonaghy 'from }\end{array}$ & film-english.com \\
\hline
\end{tabular}




\begin{tabular}{|c|c|c|c|}
\hline 9 & $\begin{array}{l}\text { Listening } \\
\text { comprehension } \\
\text { based on a short } \\
\text { movie }\end{array}$ & (Taking Flight) from & film-english.com \\
\hline 10 & $\begin{array}{l}\text { Listening to } \\
\text { long } \\
\text { conversation }\end{array}$ & Money & $\begin{array}{l}\text { https://www.er- } \\
\text { central.com/listening- } \\
\text { reader/?id=856 }\end{array}$ \\
\hline
\end{tabular}

\section{Instruments}

There were three kinds of research instruments, i.e.,the listening strategy awareness questionnaire, the learning style questionnaire, and the interview. Firstly, a listening strategy awareness questionnaire refers to Metacognitive Awareness Listening Questionnaire (MALQ) (Vandergrift et al., 2006). The questionnaire contains 21 items. Each item is rated on a six-point Likert scalefrom 1 (strongly disagree) to 6 (strongly agree) without a neutral point so that respondents cannot hedge (M Rahimi \& M. Katal, 2013). The questionnaire comprises five factors including problem-solving ( 6 items), planningevaluation (5 items), mental translation ( 3 items), person knowledge (3 items), and directed attention (4 items). The questionnaire uses a 6 - point Likert scale to elicit students' responses, ranging from 'strongly disagree' to 'strongly agree.'

The listening strategy questionnaire of MALQ (Vandergrift et al, 2006) is acceptable questionnaire that was used recently by various researchers for investigating EFL Learners' perceptions of Listening instruction (Al-Alwan et al, 2013; Bidabadi \& Yamat, 2013; Selamat \& Sidhu, 2013; Rahimi \& Katal, 2012, Tafarojiyeganeh, 2013; Harputlu, 2014; Altuwairesh, 2016; Dong, 2016). The reliability coefficient of the subscales was estimated by internal consistency method, and the Cronbach's alphas were found to be 0.74 for problem-solving, 0.75 for planning-evaluation, 0.78 for mental translation, 0.74 for person knowledge, and 0.68 for directed attention respectively (Vandergrift et al. 2006). All internal consistency for the Subscales of strategy Questionnaire is included in good level (DeVellis, 2012).

The questionnaire uses a 6- point Likert scale to elicit students' responses, ranging from 'strongly disagree' to 'strongly agree.' The questionnaire's subscales and the items can be seen in Table 2.

Table 2 The Questionnaire's Subscales

\begin{tabular}{ll}
\hline The Subscales of The Strategy Questionnaire & \multicolumn{1}{c}{ Number of Items } \\
\hline Planning and translation & $1,10,14,20,21$ \\
Directed attention & $2,6,12,16$ \\
Mental translation & $4,11,18$ \\
Problem solving & $5,7,9,13,17,19$ \\
Problem knowledge & $3,8,15$ \\
\hline
\end{tabular}

The second questionnaire was related to Students' Learning Style Questionnaire is one of the questionnairesused for obtaining information from the subjects of the research dealing 
with their learning styles by using questionnaire sheet. According to McMillan \& Schumacher (2001), the questionnaireis widely conducted as the techniques to gain information from the participants using whether in questions form or statements. The questionnaire of VAK learning styles is widelyapplied in education history to reflect on the importance of identifying learner's characteristics to enable effective education (Hamdani, 2015). Therefore, studentswere asked to fulfill the questionnaire that was provided with learning situation/s that can accommodate their different learning styles.

The 36 items of statements were arranged adapted from various sources with Visual, Auditory, and Kinesthetic (VAK) learning styles model adapted from different sources (Fu, 2009; TCM, 2017;Honey, 2006; Mansur HR, 2013;Gilakjani, 2011). The VAK learning style questionnaire consists of 36 items with Likert scale,i.e., Number 1 (never), 2 (rarely), 3 (sometimes), and 4 (often). Before applying in the process of the research, the items of statements were validated from 45 items that were arranged. They were validatedstatistically after they have been tried out to $16 \mathrm{EFL}$ student teachers at Unimus. Every piece of the statement was completed by its Indonesian translationin order that they responded the questionnaire attentively and did not have a misunderstanding. After getting the analyses results, the students then were classified into three groups including visual learners, auditorylearners, and kinesthetic learners.

The third instrument for gathering data is a semi-structured interview that was used to elicit information regarding students' ideas and reflections. This interview questionwas "semistructured,and designed to explorethe extent, nature, and qualityof theparticipants'thoughts and feelings about a rangeof personal interpersonal, and behavioral phenomena"(Creswell, 2009). Considering to Andreson's \& Arsenault's (2005) studies, it was utilized in this study to be given to representative respondents in order to add greater depth of understanding to issues dealing with the treatment. The interview was self-designed referred to the interview guideline of listening strategy by researchers (Guan, 2014, Selamat\& Sidhu, 2011) that was validated by experts before applying in the field. The semi-structured interview (students' interview protocol) consisted of ten questions were performed toward five students as representatives of experimental group students.

\section{RESULTS}

\section{The Comparison of Visual Students' Listening Strategy Awareness between Experimental Group Control Group}

The graphs presented in Figure 1 displays the comparison of students' strategy awareness between visual learners in an experimental group and visual learners in control group. Their strategy awareness analyzed based on metacognitive scales including planingevaluation, person knowledge, problem-solving, direct attention, and mental translation. 


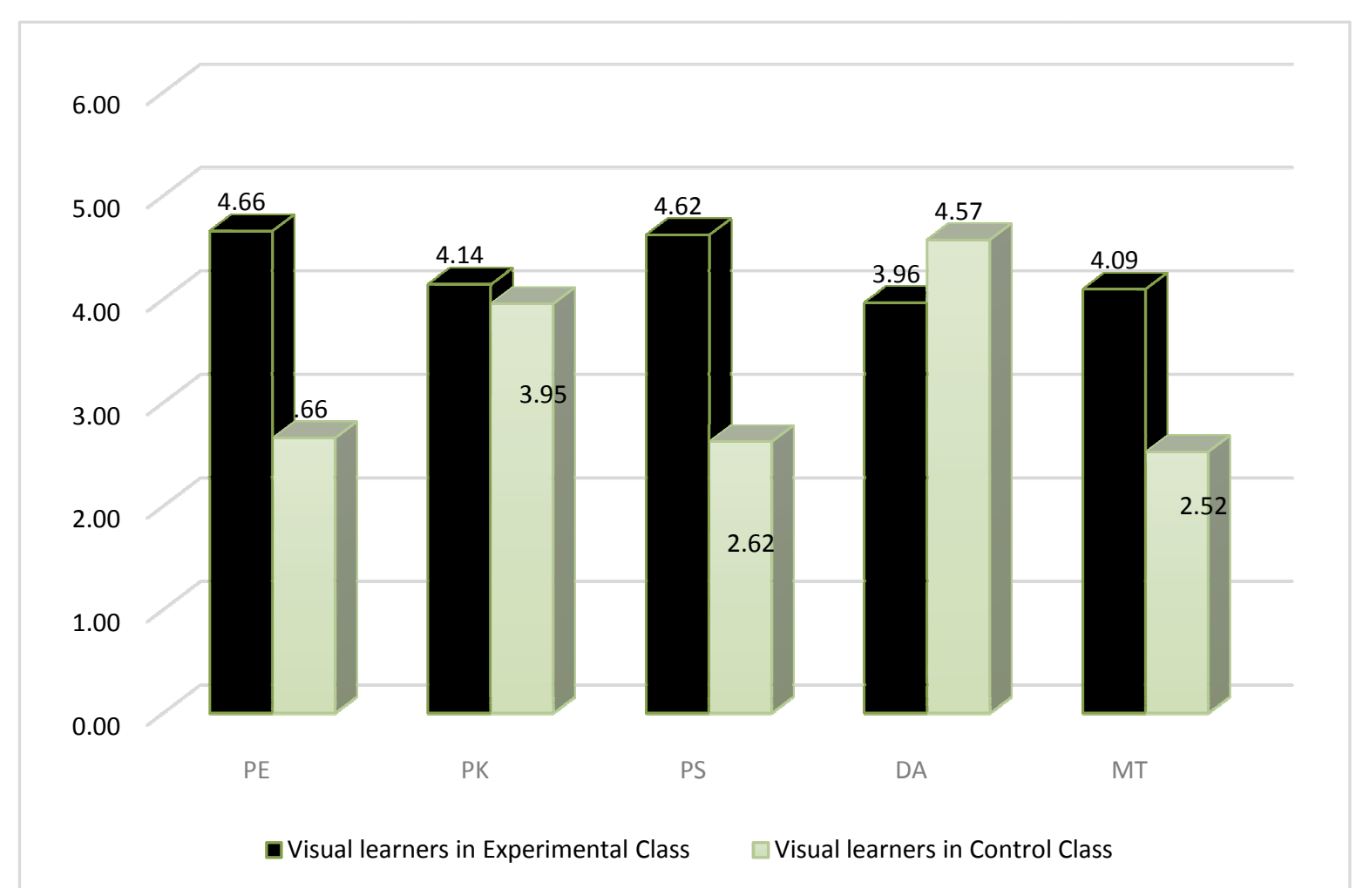

Figure 1 The Mean Scores of Visual Students' Strategy Awareness In Experimental and Control Groups

PE: Planning and Evaluation

PK: Person Knowledge

PS: Problem Solving

DA: Direct Attention

MT: Mental Translation

The results of descriptive analysis elucidate that visual learners in experimental group have a higher score in planning-evaluation, problem-solving, and mental translation than visual learners in control group.

Table 3 Independent Samples Test of Visual Learners' Response between Experimental Class and Control Class

\begin{tabular}{lrrrrr}
\multicolumn{7}{c}{ Mann-Whitney Test } \\
\hline & \multicolumn{1}{c}{ PE } & \multicolumn{1}{c}{ PK } & \multicolumn{1}{c}{ PS } & \multicolumn{1}{c}{ DA } & \multicolumn{1}{c}{ MT } \\
\hline Mann-Whitney U & 2.000 & 32.500 & .000 & 30.500 & 3.500 \\
Wilcoxon W & 38.000 & 68.500 & 36.000 & 85.500 & 39.500 \\
Z & -3.392 & -.677 & -3.586 & -.856 & -3.265 \\
Asymp. Sig. (2-tailed) & $\mathbf{. 0 0 1}$ & $\mathbf{. 4 9 9}$ & $\mathbf{. 0 0 0}$ & $\mathbf{. 3 9 2}$ & $\mathbf{. 0 0 1}$ \\
Exact Sig. [2*(1-tailed & $.000^{\mathrm{b}}$ & $.515^{\mathrm{b}}$ & $.000^{\mathrm{b}}$ & $.408^{\mathrm{b}}$ & $.000^{\mathrm{b}}$ \\
Sig.)] & & & & & \\
\hline
\end{tabular}




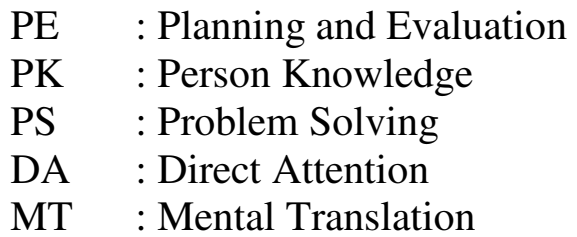

The statistical results (Table 3) displays that the differences in students' perception of three subscales of listening strategy awareness reach the significant level with Sig. (2-tailed) is lower than 5\%,i.e., $\mathrm{P}$ values for Planning evaluation, problem-solving, and mental translation are $0.001,0.000, \& 0.001$.

Meanwhile, students' listening strategies dealing with person knowledge have almost similar scores (4.14 and 3.95) for both groups. It is also proved with statistical results that Sig.(2-tailed) is 0.499 as an insignificant difference of visual learners' strategy awareness of person knowledge between experimental and control group.

Conversely, listening strategies related to direct attention was more highly possessed by control visual learners than experimental visual learners. This present finding implies that control class influence students' strategy awareness of directattention less than control class. However, the scores of direct attention listening strategy awareness are still in highlevel criteria with score 3.96 and 4.57 out of the rate 1-6 points. It is also proved with the statistical analyses with Sig. (2-tailed) 0.392.

\section{The Comparison Auditory Students' Listening Strategy Awareness between Experimental and Control Group}

As it is manifested in Figure 2, mean scores of every subscale of Auditory Students' Strategy Awareness in Experimental Group is higher than in Control group with mean scores above 4 points. The two highest mean scores are planning-evaluation and problem solving with the scores 4.93 and 4.75. Meanwhile, in control group, students' listening strategy awareness that has satisfactory above 4 points are two subscales. They are person knowledge that has similar scores to the experimental one and direct attention that is slightly higher than the auditory experimental students' direct attention. 


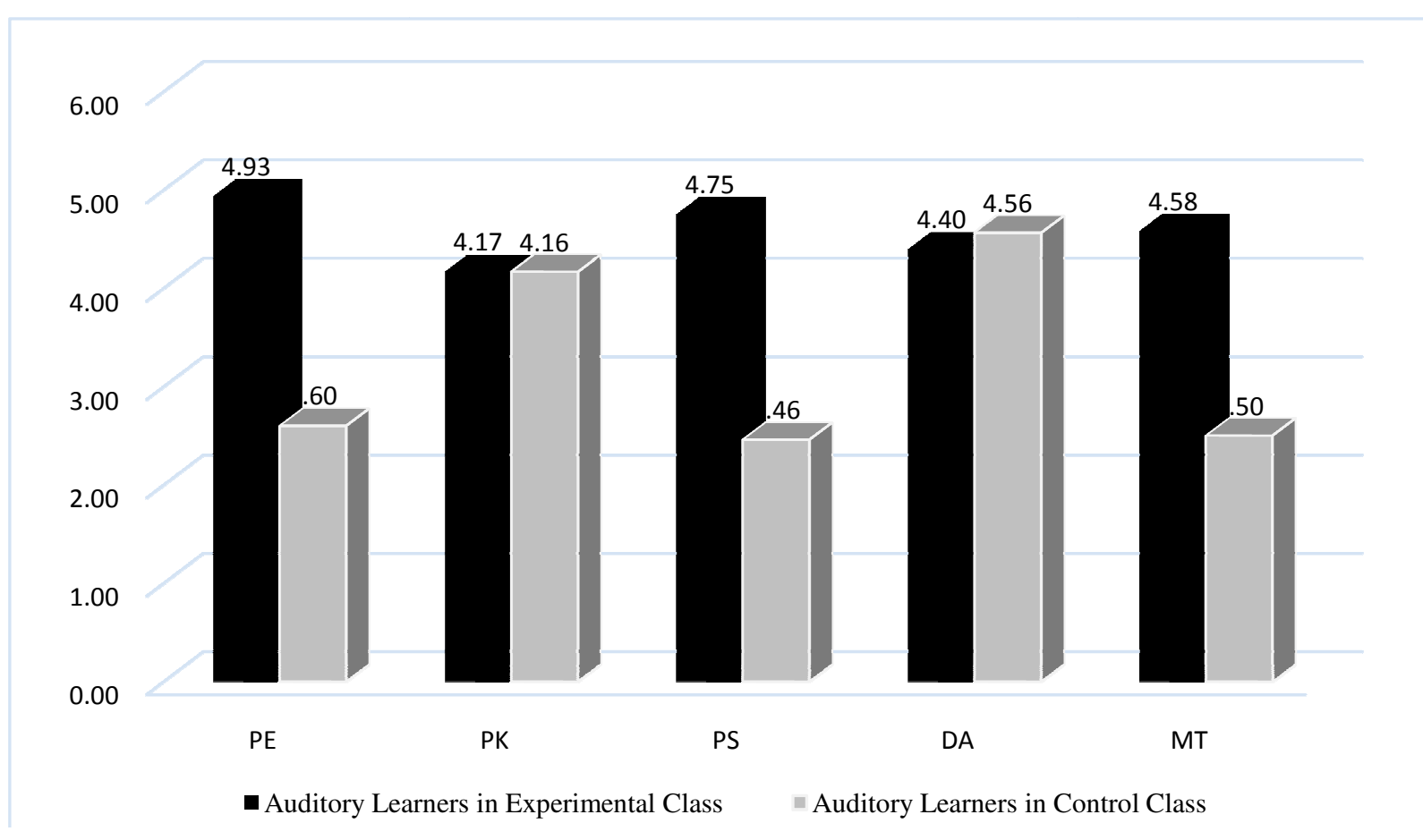

Figure 2 Means Scores of Auditory Students' Strategy Awareness in Experimental Group and Control Group

PE: Planning and Evaluation

PK: Person Knowledge

PS: Problem Solving

DA: Direct Attention

MT: Mental Translation

On the contrary, means of the score for planning-evaluation, problem-solving, and mental translation of control students have unsatisfactory scores with below 3 points.

Table 4 Independent Samples Test of Auditory Learners' Response between Experimental Class and Control Class

\begin{tabular}{lrrrrr}
\multicolumn{7}{c}{ Mann-Whitney Test } \\
\hline & \multicolumn{1}{c}{ PE } & \multicolumn{1}{c}{ PK } & \multicolumn{1}{c}{ PS } & \multicolumn{1}{l}{ DA } & \multicolumn{1}{c}{ MT } \\
\hline Mann-Whitney U & .000 & 20.500 & .000 & 19.000 & .000 \\
Wilcoxon W & 10.000 & 30.500 & 10.000 & 85.000 & 10.000 \\
Z & -2.885 & -.198 & -2.880 & -.396 & -2.896 \\
Asymp. Sig. (2-tailed) & $\mathbf{. 0 0 4}$ & $\mathbf{. 8 4 3}$ & $\mathbf{. 0 0 4}$ & $\mathbf{. 6 9 2}$ & $\mathbf{. 0 0 4}$ \\
Exact Sig. [2*(1-tailed & $.001^{\text {b }}$ & $.851^{\text {b }}$ & $.001^{\mathrm{b}}$ & $.753^{\mathrm{b}}$ & $.001^{\mathrm{b}}$ \\
Sig.)] & & & & & \\
\hline
\end{tabular}

$$
\begin{array}{ll}
\text { PE } & \text { : Planning and Evaluation } \\
\text { PK } & \text { : Person Knowledge } \\
\text { PS } & \text { : Problem Solving } \\
\text { DA } & \text { : Direct Attention } \\
\text { MT } & \text { : Mental Translation }
\end{array}
$$


The significance level of listening strategy awareness between experimental and control students as the statistical results shows that for Planning-evaluation, Problem solving, and mental translation has a significant difference for both groups with the P-values are below statistical significance 0.05 with same scores 0.004 . On the contrary, the statistical results of person knowledge and direct attention do not reach the significance level with Sig. (2tailed) 0.843 and 0.692 .

\section{The Comparison of Kinesthetic Students' Strategy Awareness between Experimental Group and Control Group}

The graphic illustration as shown in Figure 3 discloses that Kinesthetic learners in experimental group have a higher score for all subscales including planning and evaluation, person knowledge, problem-solving, direct attention, and mental translation than kinesthetic learners in control group. Kinesthetic learners who have got an explicit instruction had scores above 4 for each subscale of listening strategy awareness scores.

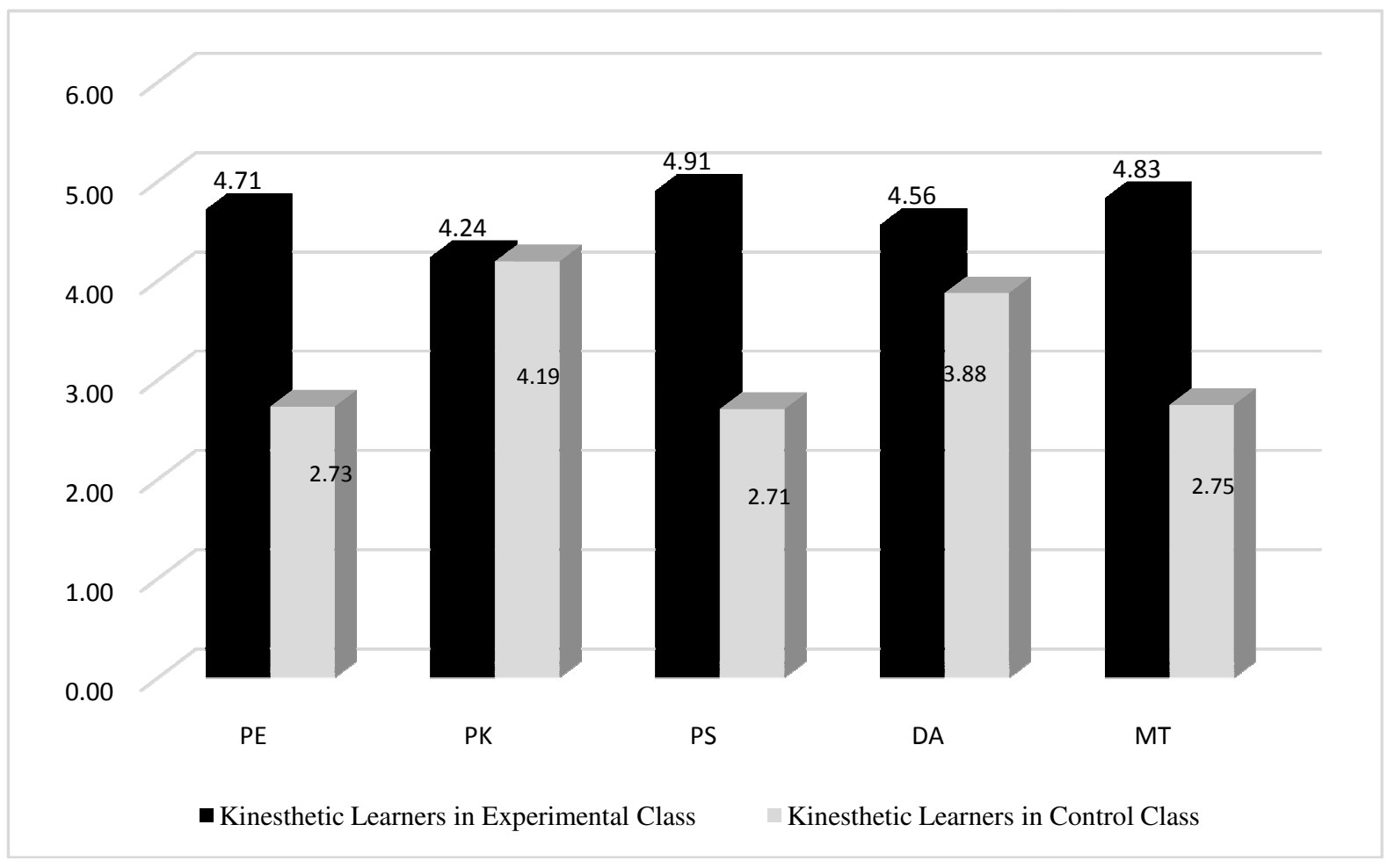

Figure 3 Means Scores of Kinesthetic Students' Strategy Awareness in Experimental Group and Control Group

PE: Planning and Evaluation

PK: Person Knowledge

PS: Problem Solving

DA: Direct Attention

MT: Mental Translation

Their person knowledge is 2.73 , problem-solving is 2.71 , and mental translation is 2.75 . However, the scores of Person knowledge and direct attention are satisfactory. Their personknowledge got a score above 4 points, and problem-solving got the score above 3 . In 
addition, the independent samples t-test was utilized. Two subscales of listening strategy awareness have significant differences between control and experimental group. They are planning evaluation, problem-solving, and mental translation with p-values are lower than significance level 0.05 with scores of the sig. (2-tailed) $0.000,0.000$, and 0.007.

Table 5 Independent Samples Test of Kinesthetic Learners' Response between Experimental Class and Control Class

Mann-Whitney Test

\begin{tabular}{lrrrrr}
\hline & \multicolumn{1}{c}{ PE } & \multicolumn{1}{c}{ PK } & \multicolumn{1}{c}{ PS } & \multicolumn{1}{c}{ DA } & \multicolumn{1}{c}{ MT } \\
\hline Mann-Whitney U & 1.500 & 42.000 & .000 & 39.000 & 12.000 \\
Wilcoxon W & 92.500 & 133.000 & 91.000 & 130.000 & 103.000 \\
Z & -3.508 & -.282 & -3.616 & -.523 & -2.683 \\
Asymp. Sig. (2-tailed) & $\mathbf{. 0 0 0}$ & $\mathbf{. 7 7 8}$ & $\mathbf{. 0 0 0}$ & $\mathbf{. 6 0 1}$ & $\mathbf{. 0 0 7}^{\text {bo }}$ \\
Exact Sig. [2*(1-tailed Sig.)] & $.000^{\mathrm{b}}$ & $.817^{\mathrm{b}}$ & $.000^{\mathrm{b}}$ & $.643^{\mathrm{b}}$ & $.006^{\mathrm{b}}$ \\
\hline
\end{tabular}

$\begin{array}{ll}\text { PE } & \text { : Planning and Evaluation } \\ \text { PK } & \text { : Person Knowledge } \\ \text { PS } & \text { : Problem Solving } \\ \text { DA } & \text { : Direct Attention } \\ \text { MT } & \text { : Mental Translation }\end{array}$

Hence, the results indicate that students exhibited a higher level of improvement of their strategy use after getting an explicit instruction. In the meantime, however, the rest of three subscales comprising kinesthetic learners' person knowledge and direct attention, have no significant differences with the sig. (2-tailed) are 0.778 and 0.601 . These results denote that experimental class and control class did not influence much on students' listening strategy awareness dealing withperson knowledge and direct attention for students who have kinesthetic learning style preference.

\section{DISCUSSION}

\section{Students' Strategy Awareness Viewed from Their Learning Styles}

Furthermore, Vandergrift and Goh (2012) assert that knowing the learner awareness can facilitate the listening instructor to administer listening strategy training for their students. Based on the aforementioned findings of descriptive statistics and inferential statistics using independent sample t-test, the results are discussed based on based on students' subscales of listening strategy awareness comprising planning and evaluation, person knowledge, problem-solving, direct attention, and mental translation.

\section{Planning \& Evaluation and Problem Solving}

The findings reveal that visual, kinesthetic, and auditory students' strategy awareness of planning-evaluation and problem-solvingare significantly influenced after they got control class. In contrast, as far as the control group is concerned, there was no significant difference found in both planning evaluation and problem-solving strategies. The results reveal that auditory learners pertained the highest level of listening strategy awareness of planning and evaluation. Meanwhile, the highest level of their listening strategy awareness related to problem-solving refers to kinesthetic learners. The present findings are in line with the other studies that English department students were found to be more aware of 
their problem solving and planning and evaluation strategies (Rahimi and Katal, 2012; Ratebi and Amirian, 2013).

Firstly, the present study elucidates that the implementation of explicit instruction of listening strategies influenced students' planning and evaluation. Based on the observation of the learning process for each meeting, they followed the step of planning and evaluation process enthusiastically. They practiced this planning strategy by giving their opinionson their real-life experience with several questions related to the topics. Indeed, it arguesSelamat's and Sidhu's (2013) study that first-year students from the Faculty of Education in a public university in Malaysia did not fully utilize the strategies of planning and evaluation to assist in their listening comprehension after having experienced instructions in listening strategies.

Furthermore, the conceivable listening strategies that influenced students' planning and evaluation are the explicit instruction of background knowledge activation and the explicit explanation the listening goal could increase learners' strategy awareness dealing with planning evaluationstrategies. EFL Students will have a plan in their head about what they would listen. It is proved by the students' responses and enthusiasm in following the strategy for activating their background knowledge for every meeting. Some students also stated one of the interesting strategies of learning process was activating their prior knowledge considered the planning process. For instance, one of students 'Student A' give in inferences based on their notes by saying 'if we are going to travel we can change negative perceptions for other people'. Then, 'Student B' said 'tourism have beneficial for connecting people and having relationships'. They also could grasp the meaning of the oral text by thinking of the similar text that they may have listened to because they tried to evaluate their comprehension. These findings are in line with (Bidabadi's and Yamat's, 2013) study that the learners are involved in preparation and planning in association with a learning goal, they are thinking about what they need or want and how they intend to achieve it. Therefore, realizing the listening strategy awareness of planning and evaluation, EFL students are able to pinpoint what is to be achieved while selecting and utilizing specific strategies for enhancing their comprehension.

Secondly, the listening instruction of listening strategies also encouraged students to do activities in accordance with problem-solving. Altuwairesh' (2016) research findings are in line with the present study that EFL learners in King Saud University report the use of problem-solving strategies is more than the other types of metacognitive listening strategies. The study conducted by (Ratebi \& Amirian, 2013)also supported the present study finding that metacognitive awareness for problem-solving had the highest score for EFL learners in Iranian University. Thus, listening strategies associated with the explicit instruction of the strategies including making an inference, listening tokeywords, and recognizing unfamiliar words. Moreover, Rahimi's and Katal's (2012) study supported this finding that in-depth analysis of factors in MALQ factors revealed that Iranian EFL students are more aware of problem-solving strategies than other strategy types. Their research found they commonly use known words and the general idea of text to deduce the meaning of unknown words and monitor the accuracy of the inference. 


\section{Mental Translation}

Another higher level of listening strategy awareness for experimental students than control group is a mental translation. The strategies of mental translation refer to the strategies that listeners must learn to avoid if they are to become skilled listeners (Vandergrift, 2003 cited in Tafarojiyeganeh, 2013). All experimental students with different learning styles have also experienced these mental translation strategies significantly except for visual learners. It can be deduced from this finding, the students' questionnaire responses that strategies potentially impact on this mental translation are interpreting the meaning in their head and translating keywords that they have listened are the most frequent ways to understanding the oral text. It is in line with students' sharing in the process of teaching and learning, at the eight meeting, named 'Student C' and 'Student D' that their common strategies to understand the listening text by translating into Bahasa Indonesia. These results corroborate the study by Harputlu (2014), the students that utilize these strategies activate their first language, and it may interfere with attention to overall processing of input. However, Altuwairesh (2016) found contrary findings that mental translation is the least used by EFL learners.

\section{Person Knowledge}

Vandergrift et al.( 2006) define person knowledge students' apprehension of the hardship of listening skill and the associated anxiety and a lack of confidence while listening English. Descriptive statistics show high scores of students' strategy awareness of person knowledge for both groups. Visual learners in control group have a higher strategy awareness dealing with person knowledge than in an experimental group. Then, auditory has similar scores for both groups. Meanwhile, a bit higher score of person knowledge possessed by the kinesthetic learners in the experimental group. As a result, all students in both groups experienced person knowledge including their point of view of listening difficulties as part of person knowledge strategy awareness. Actually, this personknowledgeis corroborated with the fact for every meeting where most students felt challenging to get the main ideas of the listening text, and they needed to listen more than once to make sure the answers.

However, the inferentially statistical findings in this study elucidate there are no significant differences between experimental and control group. This finding is in line with Ratebi's and Amirian's (2013) study that person knowledge strategy awareness had no significant improvement for EFL learners in Iranian University. It was also supported by Altuwairesh's (2016) that the person knowledge strategies are the least metacognitive listening strategies used by the female Saudi students at the College of Languages \& Translation (henceforth COLT) at King Saud University.

\section{Direct Attention}

This use of direct attention strategies allowed learners to focus their attention on what they were doing. This strategy was proposed by (O'Malley \& Chamot, 1995) with the purpose of making students aware of the importance of deciding in advance to focus on particular tasks by ignoring distractions. Although, the differences in students' listening strategy awareness of direct attention is not significant, descriptively listening strategy instructions either experimental class or control class have raised students' direct attention strategies. Indeed, visual and auditory learners in control groups have higher scores of it than in an experimental group. 
Based the statements of the questionnaire they responded, for instances, a student 'Student E' avoided the translation strategy. She said 'just focus on listening to main Idea' when they had trouble to understand what they were listening to. They focused harder on the oral text, and when their mind wandered, they recover their concentration right away. This finding was supported by the viewpoint of Bidabadi and Yamat (2013), the direct attention strategies indicate that the learners employ such strategies to keep their concentration and stay focused to overcome the difficulties they face while listening to English texts. Patricia and Hernández (2012) also asserted that their study findings demonstrated that college students used direct attention most frequently when they were experienced in strategy training. This finding is also pertinent with Altuwairesh's (2016)study that the participants $(\mathrm{N}=82)$ Arabian EFL students use directed attention strategies more commonly than the other metacognitive listening strategies. Regarding the findings of students' strategy awareness in this study, the explicit strategy instruction has been the alternative way to promote students' awareness of listening strategies in order to make them autonomous learners especially for improving their planning evaluation and their ability to solve their problems. These findingswere supported by Malik's et al. (2013) study that the explicit strategy training for twenty-nine experimental students pre-university English program of International Islamic University Malaysia can raise the students' strategy awareness significantly compared to the 25 students in control group.

\section{CONCLUSION}

The analysis of students' strategy awareness viewed from their learning styles shows some conclusions. First, visual, kinesthetic, and auditory students' strategy awareness of planning-evaluation and problem solving were significantly influenced after they got explicit instruction. In contrast, as far as the control group is concerned, there was no significant difference found in both of them. The highest level of planning and evaluation pertained to auditory learners, and highest level of problem-solving refers to kinesthetic learners. Furthermore, the conceivable listening strategies of M-CLS instruction that influenced students' planning and evaluation are the explicit instruction of background knowledge activation and the explicitexplanation of the listening goal. This M-CLS instruction also encouraged students to do activities in accordance withproblem-solving dealing with the activities of cognitive strategies.

Second, all experimental students with different learning styles have a better score of mental translation strategies than control students. It can be deduced from this finding, the students' questionnaire responses that strategies of interpreting the meaning in their head and translating keywords that they have listened potentially impact on students' mental translation strategy awareness. Third, descriptive statistics show high scores of students' strategy awareness of person knowledge for both groups. Visual learners in the control group have a higher strategy awareness dealing with person knowledge than in an experimental group. Then, auditory learners have similar scores for both groups, meanwhile, a bit higher score of person knowledge possessed by the kinesthetic learners in the experimental group. However, the inferentially statistical findings in this study elucidate that there are no significant differences between the experimental and control group. It implies that the explicit strategy instruction does not influence significantly to students' person knowledge awareness. Fourth, although, the differences in students' listening strategy awareness of direct attention is not significant, descriptively listening 
strategy instructions have raised students' direct attention strategies. Indeed, visual and auditory learners in control groups have higher scores of it than in an experimental group. The findings from the interview corroborated the questionnaire results that students perceive the explicit strategy instruction has facilitated learners to improve listening proficiency, create a good atmosphere in listening class, and prepare the listening instruction in teaching listening as EFL student teachers.

\section{REFERENCES}

Abdelhafid, B. (2007). Developing the Listening Skill through Cognitive Strategies: The Case of EFL First-Year Students at Abou Bakr Belkaid University. Ph.D thesis, Abou Bakr Belkaid University. Retrieved September 15, 2015 from http://dspace.univtlemcen.dz/handle/112/3732.

Abdul Malik, F., Sarudin, I., Muhamad, A. J., \& Ibrahim, E. H. E. (2013). Effects of metacognitive listening strategy training on listening comprehension and strategy use of ESL learners. World Applied Sciences Journal, 21(SPECIAL ISSUE4), 57-66. https://doi.org/10.5829/idosi.wasj.2013.21.slt1.2138

Al-Alwan, A., Asassfeh, S., \& Al-Shboul, Y. (2013). EFL learners' listening comprehension and awareness of metacognitive strategies: How are they related. International Education Studies, 6(9), 31-39. https://doi.org/10.5539/ies.v6n9p31

Alm, A. (2013). Extensive listening 2.0 with foreign language podcasts. Innovation in Language Learning and Teaching, 7(3), 266-280. https://doi.org/10.1080/17501229.2013.836207

Altuwairesh, N. (2016). EFL Saudi Undergraduate Students' Use of Metacognitive Listening Strategies. Arab World English Journal Arab World English Journal (AWEJ), 7(1), 78-93.

Amin, I. A. (2011). A Correlation Study between EFL Strategic Listening and Listening Comprehension Skills among Secondary School Students. Retrieved from http://files.eric.ed.gov/fulltext/ED527448.pdf

Andreson, G., \& Arsenault, N. (2005). Fundamentals of Educational Research (2nd ed.). Philadelphia: Falmer Press.

Bidabadi, F. S., \& Yamat, H. (2013). EFL Learners' Perceptions towards Meta-cognitive Strategy Use in English Language Listening. GEMA Online Journal of Language Studies, 13(3), 31-43.

Birjandi, P. (2012). The Impact of Metacognitive Strategy Instruction on the Listening Performance of University Students. International Journal of Linguistics, 4(2), 14851491. https://doi.org/10.1016/j.sbspro.2014.03.569

Chamot, A. U. (2004). Issues in Language Learning Strategy Research and Teaching. Electronic Journal of Foreign Language Teaching, 1(1), 14-26. https://doi.org/10.1017/S0261444808005612

Chang, A. C. S., \& Millett, S. (2014). The effect of extensive listening on developing L2 
listening fluency: Some hard evidence. ELT Journal, 68(1), 31-40. https://doi.org/10.1093/elt/cct052

Creswell, J. W. (2009). Research Design: Qualitative, Quantitative, and Mixed Methods Approaches. (S. P. Inc., Ed.) (3rd ed.). USA: SAGE Publications, Inc.

DeVellis, R. . (2012). Scale development: Theory and applications. California: Sage.

Dong, J. (2016). A dynamic systems theory approach to development of listening strategy use and listening performance. System, 63, 149-165. https://doi.org/10.1016/j.system.2016.10.004

Field, J. (2008). Listening in the language classroom. UK Cambridge: Cambridge University Press.

Fitrianingsih, A., \& Udin, S. (2017). Pedagogical Strategies and Content Knowledge of the Teacher of English for Maths in the Context of Content-Based Instruction. Language Circle: Journal of Language and Literature, 12(1), 11-18.

Fu, J. (2009). A Study of Learning Styles, Teaching Styles and Vocabulary Teaching Strategies in Chinese Primary School - How Do They Differ and How Can They Be Integrated? Learning.

Gilakjani, A. P. (2011). Visual, Auditory, Kinaesthetic Learning Styles and Their Impacts on English Language Teaching. Journal of Studies in Education, 2(1), 104-113. https://doi.org/10.5296/jse.v2i1.1007

Graham, S., Santos, D., \& Vanderplank, R. (2008). Listening comprehension and strategy use: A longitudinal exploration. System, 36(1), 52-68. https://doi.org/10.1016/j.system.2007.11.001

Guan, Y. (2014). The Effects of Explicit Listening Strategy Instruction on the Listening Comprehension of English as Second Language ( ESL ) Community College Students. $\mathrm{Ph} . \mathrm{D}$ Thesis. University of San Francisco. Retrieved September 15, 2015 from http://repository.usfca.edu/diss.

Hamdani, D. Al. (2015). Exploring Students' Learning Style at a Gulf University: A Contributing Factor to Effective Instruction. Procedia - Social and Behavioral Sciences, 176, 124-128. https://doi.org/10.1016/j.sbspro.2015.01.452

Harputlu, L. (2014). The effects of motivation and metacognitive strategy use on EFL listening proficiency. Procedia - Social and Behavioral Sciences, 158, 124-131. https://doi.org/10.1016/j.sbspro.2014.12.056

Harris, M. (2008). Scaffolding reflective journal writing Negotiating power, play and position. Nurse Education Today, 28(3), 314-326. https://doi.org/10.1016/j.nedt.2007.06.006

Honey, P. (2006). Kolb’S Learning Styles Learning Styles. Learning Styles, 6.

Kök, İ. (2017). Relationship between Listening Comprehension Strategy Use and Listening Comprehension Proficiency Use and Listening Comprehension Proficiency. The 
International Journal of Listening, 4018(March), 1-7. https://doi.org/10.1080/10904018.2016.1276457

LEARNING FOR LISTENING: METACOGNITIVE AWARENESS AND STRATEGYUSETODEVELOP Review by Zhang Donglan. (2001), 2001(1), 21-26.

Mansur HR. (2013). Mengenal Gaya Belajar. Sulawesi Selatan. Retrieved from http://www.lpmpsulsel.net/v2/attachments/259_MENGENAL GB PESERTA DIDIK.pdf

Marzban, A., \& Isazadeh, F. (2012). Discovery Listening and Explicit Strategy-BasedInstruction Models' Effect on the Iranian Intermediate EFL Listening Comprehension. Procedia - Social and Behavioral Sciences, 46, 5435-5439. https://doi.org/10.1016/j.sbspro.2012.06.453

McMillan, J. H., \& Schumacher, S. (2001). Research in Education: a Conceptual Introduction (5th ed.). New York: Priscillia McGeehon.

Mulyadi, D. (2018). Enhancing Students' Listening Proficiency Through The Instruction of (Meta)-Cognitive Listening Strategy. Getsempena English Education Journal (GEEJ), 5(2), 168-176.

Mulyadi, D., Rukmini, D., \& Yuliasri, I. (2017). The Analysis of Students ' Listening Proficiency Viewed from Their Different Learning Styles after Getting the Strategy Instructions. Theory and Practice in Language Studies, 7(12), 1200-1209. https://doi.org/http://dx.doi.org/10.17507/tpls.0712.06

Nation, I. S. P., \& Newton, J. (2009). Teaching ESL / EFL Listening and Speaking. New York: Routledge.

O’Malley, J. M., \& Chamot, A. U. (1995). Learning Strategies in Second Language Acquisition. New York: Cambridge University Press.

Patricia, S., \& Hernández, B. (2012). Applying a Metacognitive Model of Strategic Learning for Listening Comprehension by Means of Online-Based Activities, in A College Course. Universidad de La Sabana.

Rahimi, M., \& Abedi, S. (2014). The Relationship between Listening Self-efficacy and Metacognitive Awareness of Listening Strategies. Procedia - Social and Behavioral Sciences, 98, 1454-1460. https://doi.org/10.1016/j.sbspro.2014.03.565

Rahimi, M., \& Katal, M. (2012a). Metacognitive listening strategies awareness in learning english as aforeign language: A comparison between university and high-school students. Procedia - Social and Behavioral Sciences, 31(2011), 82-89. https://doi.org/10.1016/j.sbspro.2011.12.020

Rahimi, M., \& Katal, M. (2012b). The role of metacognitive listening strategies awareness and podcast-use readiness in using podcasting for learning English as a foreign language. Computers in Human Behavior, 28(4), 1153-1161. https://doi.org/10.1016/j.chb.2012.01.025

Rahimi, M., \& M. Katal. (2013). The Impact of Metacognitive Instruction on EFL 
Learners ' Listening Comprehension and Oral Language Proficiency. The Journal of Teaching Skills (JTLS), 5(2), 69-90.

Ratebi, Z., \& Amirian, Z. (2013). The Use of Metacognitive Strategies in Listening Comprehension by Iranian University Students Majoring in English: a Comparison between High and Low Proficient Listeners. Journal of Studies in Education, 3(1). https://doi.org/10.5296/jse.v3i1.2969

Selamat, S., \& Sidhu, G. K. (2013). Enhancing Listening Comprehension: The Role of Metacognitive Strategy Instruction (MetSI). Procedia - Social and Behavioral Sciences, 90(InCULT 2012), 421-430. https://doi.org/10.1016/j.sbspro.2013.07.111

Serri, F., Boroujeni, A. J., \& Hesabi, A. (2012). Cognitive, Metacognitive, and Social/Affective Strategies in Listening Comprehension and Their Relationships with Individual Differences. Theory and Practice in Language Studies, 2(4), 843-849. https://doi.org/10.4304/tpls.2.4.843-849

Siegel, J. (2013). Second language learners' perceptions of listening strategy instruction. Innovation in Language Learning and Teaching, 7(1), 1-18. Retrieved from http://www.scopus.com/inward/record.url?eid=2-s2.084874768466\&partnerID=40\&md5=7e1664bb313bb3983872b5f2cb263244

Tafarojiyeganeh, M. (2013). Metacognitive listening strategies awareness in monolingual versus bilingual EFL learners. Procedia - Social and Behavioral Sciences, 70, 17871793. https://doi.org/10.1016/j.sbspro.2013.01.254

TCM. (2017). VAK learning styles questionnaire. Retrieved August 4, 2017, from https://www.trainingcoursematerial.com/free-assessment-tools/vak-learning-stylesquestionnaire-quiz

Vandergrift, L., \& Baker, S. (2015). Learner Variables in Second Language Listening Comprehension: An Exploratory. Language Learning, 65(June), 390-416. https://doi.org/10.1111/lang.12105

Vandergrift, L., \& Goh, C. (2009). Teaching and Testing Listening Comprehension. In M. H. Long \& C. J. Doughty (Eds.), The Handbook of Language Teaching (pp. 395411). Oxford, UK: Blackwell Publishing Ltd.

Vandergrift, L., \& Goh, C. C. . (2012). Teaching and Learning Second Language Listening: Metacognition in Action (Vol. 40). New York: Rou. https://doi.org/10.1016/j.system.2012.10.004

Vandergrift, L., Goh, C., Mareschal, C. J., \& Tafaghodtari, M. H. (2006). The metacognitive awareness listening questionnaire: Development and validation. Language Learning, 56(3), 431-462. https://doi.org/10.1111/j.14679922.2006.00373.x

$\mathrm{Xu}, \mathrm{W}$. (2011). Learning Styles and Their Implications in Learning and Teaching. Theory and Practice in Language Studies, 1(4), 413-416. https://doi.org/10.4304/tpls.1.4.413-416 